\section{Preemergence Herbicide Efficacy for Crabgrass (Digitaria spp.) Control in Common Bermudagrass Managed under Different Mowing Heights}

\author{
Travis W. Gannon ${ }^{1}$ and Matthew D. Jeffries \\ Department of Crop Science, North Carolina State University, Campus Box \\ 7620, 4402 Williams Hall, Raleigh, NC 27695
}

James T. Brosnan and Gregory K. Breeden Department of Plant Sciences, University of Tennessee, 252 Ellington Plant Sciences Building, 2431 Joe Johnson Drive, Knoxville, TN 37996

\author{
Kevin A. Tucker and Gerald M. Henry \\ Department of Crop and Soil Sciences, University of Georgia, 3111 Miller \\ Plant Sciences Building, Athens, GA 30602
}

Additional index words. cultural practices, dithiopyr, indaziflam, integrated pest management, oxadiazon, pendimethalin, prodiamine, sulfentrazone, turf, turfgrass

\begin{abstract}
Research was conducted at multiple locations throughout the southeastern United States during 2012 and 2013 to assist turf managers in developing integrated programs for managing crabgrass in common bermudagrass turf. Our objective was to determine the effect of mowing height on the efficacy of several pre-emergent (PRE) herbicides labeled for crabgrass control in bermudagrass turf. Plots were established in Raleigh, NC (NCSU), Knoxville, TN (ETREC), and Winder, GA (UGA) and treated with a factorial combination of two mowing heights $(1.5$ or $3.8 \mathrm{~cm})$, two application regimes [single or split application (initial and an 8-week sequential)], and six preemergent herbicides (dithiopyr, indaziflam, oxadiazon, pendimethalin, prodiamine, and prodiamine + sulfentrazone). In 2012, all herbicides provided greater crabgrass control on plots maintained at $3.8 \mathrm{~cm}$ compared with $1.5 \mathrm{~cm}$. This response was not detected in 2013 , potentially as a result of above-average rainfall at two of the three trial locations. Analysis revealed mowing height did not affect pendimethalin soil residue, whereas prodiamine concentrations from bermudagrass maintained at $1.5 \mathrm{~cm}$ were greater than bermudagrass maintained at $3.8 \mathrm{~cm}$. Therefore, differences in crabgrass control in bermudagrass maintained under different mowing heights may be the result of plant growth, reduced photosynthetically active radiation $(P A R)$ at the soil surface, among other reasons, and not solely differential degradation of applied herbicides at the 1.5- and 3.8-cm mowing heights. Future research should explore effects of increasing bermudagrass mowing height on $P A R$ required for crabgrass germination and growth.
\end{abstract}

Crabgrass (Digitaria spp.) is a common weed of warm- and cool-season turfgrasses. A survey of the southern United States conducted by Webster (2000) ranked crabgrass as the most common turfgrass weed in 10 of 12 southern states. Compared with desirable turfgrass species such as bermudagrass (Cynodon spp.) or tall fescue (Lolium arundinaceum Schreb.), the light green color and coarse texture of crabgrass foliage can reduce overall turf quality (Hall et al., 1994). PRE herbicides such as dithiopyr, indaziflam, oxadiazon, prodiamine, and pendimethalin are labeled for selective control of smooth crabgrass (Digitaria ischaemum Schreb.) and large crabgrass [Digitaria sanguinalis (L.) Scop.]

Received for publication 15 July 2014. Accepted for publication 17 Oct. 2014.

${ }^{1}$ To whom reprint requests should be addressed; e-mail travis_gannon@ncsu.edu. turfgrass species such as common bermudagrass (Cynodon dactylon L.) (Callahan, 1978; Hoyle et al., 2014).

Integrated pest management has been defined as the thoughtful combination of multiple approaches such as synthetic chemical applications and cultural practices to control pests (Busey, 2003). Although the efficacy of PRE herbicides for crabgrass control and effects of mowing height on crabgrass incidence have been studied, research exploring the integration of these two practices is limited. Dernoeden et al. (1993) monitored smooth crabgrass cover after applications of dithiopyr and pendimethalin to tall fescue turf maintained at $8.8,5.5$, and $3.2 \mathrm{~cm}$. Herbicide rates were reduced by $50 \%$ at the end of the 3 -year study and plots mowed at 5.5 and $8.8 \mathrm{~cm}$ did not require a herbicide in the final year of the experiment. Smooth crabgrass cover in dithiopyr- or pendimethalin-treated plots was similar ( $3 \%$ or less) during the first 2 years of the study, regardless of mowing height. However, in the third year, smooth crabgrass cover was greater in tall fescue turf mowed at 3.2 and $5.5 \mathrm{~cm}$ than $8.8 \mathrm{~cm}$ after pendimethalin or dithiopyr application. The researchers concluded that annual dithiopyr or pendimethalin applications at labeled rates would be required when mowing tall fescue at 3.2 and $5.5 \mathrm{~cm}$. However, reduced rates and less frequent applications of these herbicides could provide acceptable turf quality when mowing height was increased to $8.8 \mathrm{~cm}$.

Changes in common bermudagrass mowing height may affect the efficacy of PRE herbicides labeled for crabgrass control. However, minimal data have been published regarding integrated programs for managing crabgrass infestations using PRE herbicides in combination with mowing height adjustment. Therefore, the objective of this research was to determine the effect of mowing height on the efficacy of several PRE herbicides labeled for crabgrass control in common bermudagrass turf.

\section{Materials and Methods}

in turf (Anonymous, 2012a, 2012b, 2012c, 2007, 2009).

Previous research has reported reductions in crabgrass cover by increasing turf mowing height. Specifically, Dernoeden et al. (1993) reported $\approx 3 \%$ smooth crabgrass cover in non-treated tall fescue mowed at $8.8 \mathrm{~cm}$ compared with $40 \%$ and $80 \%$ smooth crabgrass cover in plots mowed at 5.5 and $3.2 \mathrm{~cm}$, respectively, at the conclusion of a 3-year study. Reductions in smooth crabgrass cover with increased mowing height have been observed in other cool-season turfgrass species, including kentucky bluegrass ( $\mathrm{Poa}$ pratensis L.), tall fescue, perennial ryegrass (Lolium perenne L.), and several fine fescue species (Festuca spp.) (Debels et al., 2012; Dernoeden et al., 1998; Dunn et al., 1981; Jagschitz and Ebdon, 1985; Voigt et al., 2001). To date, minimal information has been published regarding effects of mowing height on crabgrass cover in warm-season
Field study. Field research to evaluate select PRE herbicides labeled for crabgrass control in common bermudagrass turf managed under different mowing heights was conducted at the East Tennessee Research and Education Center-Plant Sciences Unit (ETREC) in Knoxville, TN (lat. $35.54^{\circ} \mathrm{N}$, long. $83.57^{\circ} \mathrm{W}$ ) during 2012 and 2013. This experiment was repeated in 2013 at North Carolina State University Turf Field Laboratory (NCSU) in Raleigh, $\mathrm{NC}$ (lat. $35.73^{\circ} \mathrm{N}$, long. $78.67^{\circ} \mathrm{W}$ ) and Pine Hills Golf Club (UGA) in Winder, GA (lat. $33.97^{\circ} \mathrm{N}$, long. $\left.83.69^{\circ} \mathrm{W}\right)$ to evaluate treatment response across a wider geographic region of the southeastern United States.

At all locations, research was conducted on established common bermudagrass. At NCSU and ETREC, plots $(1 \times 2.5 \mathrm{~m}$ and $1.5 \times 2.4 \mathrm{~m}$, respectively) were established in areas with a history of smooth crabgrass incidence, whereas large crabgrass was the predominant species at 
UGA $(1.5 \times 3-\mathrm{m}$ plots $)$. Soil type at NCSU was a Cecil sandy clay loam (fine, kaolinitic, thermic typic Kanhapludult), measuring 6.4 in soil $\mathrm{pH}$ and $1.9 \%$ in organic matter. Soil type at ETREC was a Sequatchie loam soil (fine-loamy, siliceous, semiactive, thermic humic Hapludult), measuring 6.2 in soil $\mathrm{pH}$ and $2.1 \%$ in organic matter. At the UGA location, soil was a Madison sandy clay loam (fine, kaolinitic, thermic typic Kanhapludult) with a $\mathrm{pH}$ of 5.1 and $0.7 \%$ organic matter. In both years, turf at ETREC received two fertilizer applications at $49 \mathrm{~kg}$ nitrogen $(\mathrm{N}) /$ ha in spring (March, April) from a complete fertilizer $\left(21.0 \mathrm{~N}-0.4 \mathrm{P}_{2} \mathrm{O}_{5}-13.3 \mathrm{~K}_{2} \mathrm{O}\right.$; Harrell's LLC, Charlotte, NC). Supplemental nutrition was applied similarly at NCSU with two applications (April, June) made at $49 \mathrm{~kg} \mathrm{~N} /$ ha from a complete fertilizer $(25.0 \mathrm{~N}-$ $\left(16.0 \mathrm{~N}-1.7 \mathrm{P}_{2} \mathrm{O}_{5}-6.6 \mathrm{~K}_{2} \mathrm{O}\right.$; Griggs Brothers, Albion, ID) was applied at UGA at a rate of $49 \mathrm{~kg} \mathrm{~N} / \mathrm{ha}$ in April and June. To prevent wilt, overhead irrigation was applied to supplement rainfall at each location. Additionally, plots at all locations received $\approx 0.5 \mathrm{~cm}$ of applications.

Treatments included a factorial combination of two mowing heights $(1.5$ or $3.8 \mathrm{~cm})$, two application regimes (single or split applications with split treatments applied at initial application and 8 weeks later), and six PRE herbicides including: dithiopyr (Dimension; Dow AgroSciences, Indianapolis, 2.6 $\mathrm{P}_{2} \mathrm{O}_{5}-10.0 \mathrm{~K}_{2} \mathrm{O}$; Harrell's LLC). Fertilizer irrigation within $24 \mathrm{~h}$ of herbicide or fertilizer

IN), indaziflam (Specticle; Bayer Environmental Sciences, Research Triangle Park, NC), oxadiazon (Ronstar; Bayer Environmental Sciences), pendimethalin (Pendulum AquaCap; BASF Corporation, Research Triangle Park, NC), prodiamine (Barricade; Syngenta Professional Products, Greensboro, $\mathrm{NC}$ ), and prodiamine + sulfentrazone (Echelon; FMC Corporation, Philadelphia, PA). Herbicide application rates and dates are presented in Tables 1 and 2. All herbicides except oxadiazon used water as the carrier and were applied with $\mathrm{CO}_{2}$-powered backpack sprayers at all locations. Carrier volumes at ETREC, NSCU, and UGA were 280, 304 , and $280 \mathrm{~L} \cdot \mathrm{ha}^{-1}$, respectively, using flatfan nozzles (XR8002; TeeJet Technologies, Wheaton, IL). A granular formulation of oxadiazon was applied at all locations with a shaker jar.

Plots were mowed at 1.5 or $3.8 \mathrm{~cm}$ at all locations beginning 4 weeks before herbicide treatment. Plots maintained at $1.5 \mathrm{~cm}$ were mowed three times per week, whereas those maintained at $3.8 \mathrm{~cm}$ were mowed two times per week. In all cases, clippings were returned. ETREC maintained $1.5-\mathrm{cm}$ and $3.8-\mathrm{cm}$ plots with reel (Jacobsen LF 3800 ; Jacobsen, A Textron Company, Charlotte, NC) and rotary (Gravely Zero Turn; An Ariens Company, Brillion, WI) mowers, respectively. Rotary mowers were used to maintain both 1.5-cm (Honda HRC 215; American Honda Motor Company, Duluth, GA) and 3.8-cm (John Deere 997 Zero-Turn;

Table 1. Preemergent herbicide treatments evaluated in Knoxville, TN, Raleigh, NC, and Winder, GA, during 2012 and 2013. ${ }^{z}$

\begin{tabular}{lll}
\hline Application regime $^{\mathrm{y}}$ & \multicolumn{1}{c}{ Herbicide } & \multicolumn{1}{c}{${\text { Rate }\left(\mathrm{g} \cdot \mathrm{ha}^{-1}\right)}^{\text {Single }}$} \\
& Dithiopyr & 560 \\
& Indaziflam & 52.5 \\
& & 35 \\
& Oxadiazon & 4,500 \\
& Pendimethalin & 3,360 \\
& Prodiamine & 1,680 \\
Split & Prodiamine + sulfentrazone & $854+416$ \\
& Dithiopyr & $280 \mathrm{fb}^{\mathrm{x}} 280$ \\
& Indaziflam & $26.25 \mathrm{fb} 26.25$ \\
& & $17.5 \mathrm{fb} 17.5$ \\
& Oxadiazon & $2,250 \mathrm{fb} 2250$ \\
& Pendimethalin & $1,680 \mathrm{fb} 1680$ \\
& Prodiamine & $840 \mathrm{fb} 840$ \\
& Prodiamine + sulfentrazone & $427+208 \mathrm{fb} 427+208$ \\
\hline
\end{tabular}

${ }^{2}$ Applications were made to common bermudagrass turf areas maintained at 1.5 and $3.8 \mathrm{~cm}$.

${ }^{y}$ All herbicides received $\approx 0.5 \mathrm{~cm}$ of irrigation or rainfall within $24 \mathrm{~h}$ of application. Split applications were applied initially and 8 weeks later.

${ }^{\mathrm{x}} \mathrm{fb}=$ followed by.
Deere and Company, Moline, IL) plots at NCSU. Plots at UGA were maintained at $1.5 \mathrm{~cm}$ with a reel mower (Toro Reelmaster 5500-D; The Toro Company, Bloomington, $\mathrm{MN}$ ) and $3.8 \mathrm{~cm}$ with a rotary mower (Toro Groundsmaster 3320; The Toro Company). Nontreated plots were also included for each mowing height.

Crabgrass control was visually evaluated on a $0 \%$ (no control) to $100 \%$ (complete control) scale $12,16,20$, and 24 weeks after initial treatment (WAIT) in 2012 and 2013. Crabgrass plant counts were also taken 24 WAIT in 2013 using a $1-\mathrm{m}^{2}$ grid $(10 \mathrm{~cm} \times$ $10 \mathrm{~cm}$ spacing) placed in the center of each plot. All count data are expressed as a percent reduction compared with the non-treated control at each respective mowing height.

The experimental design was a randomized complete block with three replications at ETREC and UGA and four replications at NCSU. Crabgrass control data were arcsinetransformed before being subjected to analysis of variance in SAS (SAS Version 9.1; SAS Institute, Cary, NC) using expected means squares described by McIntosh (1983) for multiple location experiments. Interpretations of arcsine- and non-transformed data were similar; therefore, non-transformed means are presented for clarity. Data from the 2012 and 2013 experiments were analyzed separately. Significant treatment-by-location interactions were detected in 2013 data collected at ETREC, NCSU, and UGA; therefore, data from all 2013 experiments were analyzed and presented separately. In both years, Fisher's protected least significant difference (LSD) test was used to separate treatment means at the $\alpha=0.05$ level. Pearson's correlation coefficients were also calculated to evaluate relationships between visual assessments of crabgrass control and plant counts.

Residue analysis. Laboratory experiments were conducted in 2013 to determine the effect of mowing height on prodiamine and pendimethalin residue from field research plots at ETREC and NCSU. Prodiamine and pendimethalin were selected because they are commonly used PRE herbicides in established common bermudagrass areas. Furthermore, each are dinitroaniline herbicides with varying persistence. Prodiamine and pendimethalin have moderate to persistent and short to moderate half-lives, respectively, in soil (Senseman, 2007). Single soil cores $(2.5 \times 2.5 \times 2.0 \mathrm{~cm})$

Table 2. Calendar dates and environmental conditions when applying preemergent herbicides during 2012 and 2013 in Knoxville, TN (ETREC), Raleigh, NC (NCSU), and Winder, GA (UGA).

\begin{tabular}{|c|c|c|c|c|c|c|c|}
\hline \multirow{2}{*}{$\frac{\mathrm{Yr}}{2012}$} & \multirow[b]{2}{*}{ Location } & \multirow{2}{*}{$\begin{array}{l}\text { Application } \\
\text { regime }\end{array}$} & \multirow[b]{2}{*}{ Calendar date } & Air temp & Soil temp & Avg high/low air temp during data collection & \multirow{2}{*}{$\begin{array}{c}\text { Rainfall during } \\
\text { data collection }(\mathrm{cm})\end{array}$} \\
\hline & & & & \multicolumn{3}{|c|}{-------------------------------------------- $\left({ }^{\circ} \mathrm{C}\right)$------------------------------------------ } & \\
\hline & & Split & 6 Mar. fb 30 Apr. & $20 \mathrm{fb} 31$ & $13 \mathrm{fb} 26$ & - & - \\
\hline \multirow{4}{*}{2013} & & Split & 14 Mar. fb 7 May & $6 \mathrm{fb} 21$ & $6 \mathrm{fb} 21$ & - & - \\
\hline & NCSU & Single & 15 Mar. & 9 & 8 & $25 / 14$ & 56.5 \\
\hline & & Split & 15 Mar. fb 10 May & $9 \mathrm{fb} 27$ & $8 \mathrm{fb} 23$ & - & - \\
\hline & UGA & Single & 8 Mar. & 12 & 11 & $26 / 15$ & 94.2 \\
\hline
\end{tabular}

ETREC $=$ East Tennessee Research and Education Center-Plant Sciences Unit; NCSU = North Carolina State University Turf Field Laboratory; UGA = Pine Hills Golf Club; fb = followed by. 
were collected from the center of each plot using a soil probe (AMS Inc., America Falls, ID) at 0 and 24 WAIT. Initial samples (0 WAIT) were collected by removing the above-ground vegetation in a small sampling area within the plot, thereby treating the soil and allowing the herbicides to air-dry samples were wrapped in aluminum foil and stored immediately at $-20{ }^{\circ} \mathrm{C}$ until analysis occurred.

Prodiamine and pendimethalin were extracted according to U.S. EPA Method Number 445276-01 with slight modifications as noted (U.S. Environmental Protection Agency, 1996). Ten grams of soil were placed in a $175-\mathrm{mL}$ polypropylene conical bottom centrifuge bottle and $25 \mathrm{~mL}$ deionized water was added and hand-shaken for $15 \mathrm{~s}$. Seventy-five milliliters of $2 \%$ acidic methanol was added and shaken on an orbital for $2 \mathrm{~h}$ before collecting the samples. All

shaker for $1 \mathrm{~h}$ at $240 \mathrm{rpm}$. Samples were then centrifuged for $10 \mathrm{~min}$ at $4000 \mathrm{rpm}$ and supernatant was decanted. Samples were filtered through a $0.45-\mu \mathrm{m}$ syringe filter, vialed, and analyzed by an ultra-performance liquid chromatography-tandem mass spectrometer. Residues were quantified based on peak area measurements using appropriate calibration curves with means separated using Fisher's protected LSD test at the $\alpha=$ 0.05 level.

\section{Results and Discussion}

Field study. By 24 WAIT in 2012, averaged over application regime, all PRE herbicides excluding prodiamine and indaziflam $\left(52.5 \mathrm{~g} \cdot \mathrm{ha}^{-1}\right)$ provided greater crabgrass control on plots maintained at $3.8 \mathrm{~cm}$ compared with $1.5 \mathrm{~cm}$ (Table 3 ). When applied to bermudagrass maintained at $3.8 \mathrm{~cm}$, prodiamine

Table 3. Mowing height-by-herbicide interactions in smooth crabgrass (Digitaria ischaemum) control data collected 24 weeks after treatment in Knoxville, TN (ETREC) in 2012.

\begin{tabular}{lccc}
\hline Herbicide & Rate $^{\mathrm{z}}\left(\mathrm{g} \cdot \mathrm{ha}^{-1}\right)$ & Mowing ht $(\mathrm{cm})$ & Smooth crabgrass control (\%) \\
\hline Dithiopyr & 560 & 3.8 & 79 \\
& 560 & 1.5 & 43 \\
Indaziflam & 52.5 & 3.8 & 87 \\
& 52.5 & 1.5 & 72 \\
Indaziflam & 35 & 3.8 & 77 \\
& 35 & 1.5 & 45 \\
Oxadiazon & 4,500 & 3.8 & 86 \\
& 4,500 & 1.5 & 45 \\
Pendimethalin & 3,360 & 3.8 & 78 \\
& 3,360 & 1.5 & 56 \\
Prodiamine & 1,680 & 3.8 & 97 \\
& 1,680 & 1.5 & 83 \\
Prodiamine + sulfentrazone & $854+416$ & 3.8 & 80 \\
& $854+416$ & 1.5 & 56 \\
& $\mathrm{LSD}_{0.05}$ & & 17 \\
\hline
\end{tabular}

$\overline{{ }^{\mathrm{z}} \text { Data are averaged over single and split applications. Split applications were applied initially and } 8 \text { weeks }}$ later.

ETREC $=$ East Tennessee Research and Education Center-Plant Sciences Unit; LSD = least significant difference. controlled crabgrass $97 \%$, similar to indaziflam $\left(52.5 \mathrm{~g} \cdot \mathrm{ha}^{-1}\right)$, oxadiazon, and prodiamine + sulfentrazone (Table 3).

Significant $(P<0.0001)$ location-bytreatment interactions were detected in crabgrass control and plant count data collected in 2013; therefore, data from the ETREC, NCSU, and UGA locations are presented separately. By 24 WAIT at ETREC, dithiopyr applications to bermudagrass maintained at $3.8 \mathrm{~cm}$ controlled crabgrass greater than dithiopyr applied to turf at $1.5 \mathrm{~cm}$ (Table 4). Although this is similar to findings from ETREC in 2012, this response was not observed at NCSU or UGA in 2013. At these locations, averaged over application regime, similar crabgrass control was observed with dithiopyr (62\% to $78 \%$ ) regardless of mowing height 24 WAIT (Table 4). Applications of indaziflam at $52.5 \mathrm{~g} \cdot \mathrm{ha}^{-1}$ to $3.8 \mathrm{~cm}$ turf at ETREC controlled crabgrass less than those made to turf mowed at $1.5 \mathrm{~cm}$ in 2013 . This response was also observed with indaziflam $\left(35 \mathrm{~g} \cdot \mathrm{ha}^{-1}\right)$ at NCSU (Table 4). No differences in crabgrass control with indaziflam were detected between the $3.8-$ and $1.5-\mathrm{cm}$ mowing heights at UGA in 2013; however, overall levels of crabgrass control with indaziflam at this location were low by 24 WAIT ( $20 \%$ to $41 \%)$. Similar to 2012 , prodiamine (1680 g.ha ${ }^{-1}$ ) provided excellent crabgrass control 24 WAIT (94\% to $100 \%$ ) regardless of location, mowing height, or application regime in 2013.

Location-by-application regime interactions $(P=0.02)$ were also detected in 2013 . At ETREC, single and split applications of indaziflam $\left(35 \mathrm{~g} \cdot \mathrm{ha}^{-1}\right)$ controlled crabgrass similarly; however, the level of crabgrass control with these treatments was unacceptable $(46 \%$ to $50 \%$ ) by 24 WAIT (Table 5 ). Application regime affected crabgrass control with the $35 \mathrm{~g} \cdot \mathrm{ha}^{-1}$ rate of indaziflam in

Table 4. Mowing height-by-herbicide interactions in crabgrass (Digitaria spp.) control and plant count data collected 12 and 24 weeks after treatment (WAT) in Knoxville, TN (ETREC), Raleigh, NC (NCSU), and Winder, GA (UGA) in 2013.

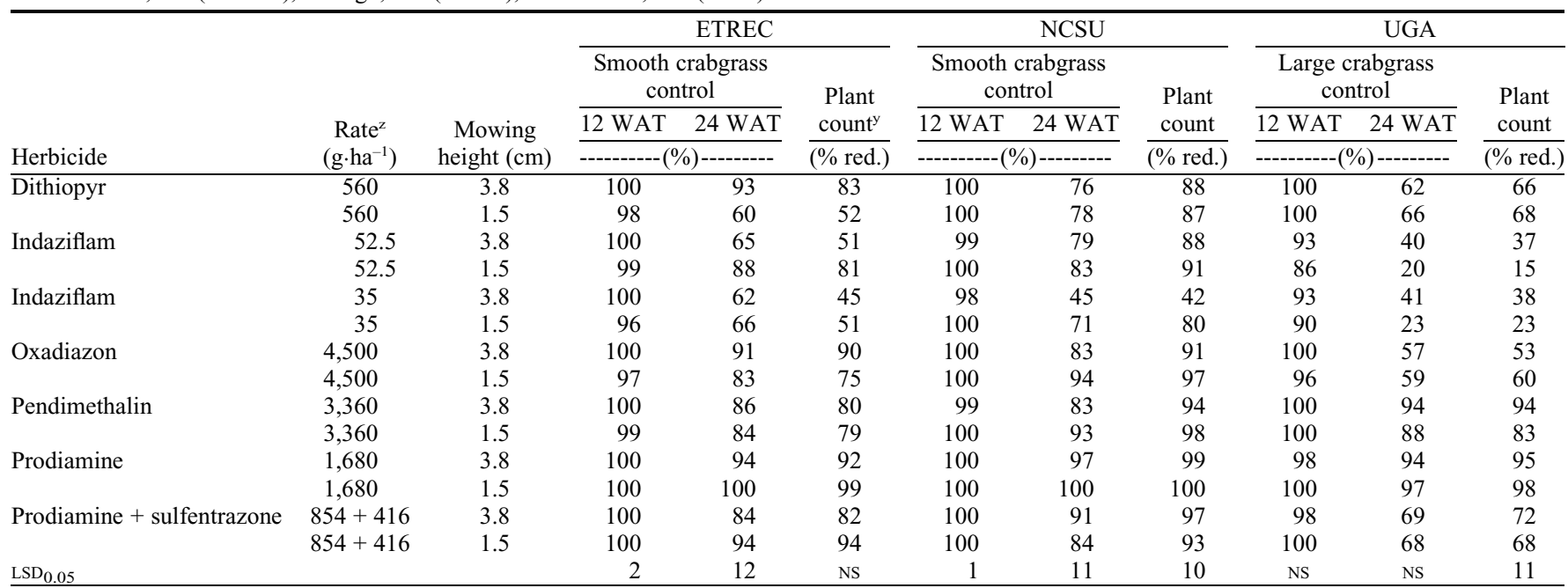

${ }^{\mathrm{z}}$ Data are averaged over single and split applications. Split applications were applied initially and 8 weeks later.

yPlant count data were collected 24 WAIT and expressed as a percent reduction relative to the non-treated control.

ETREC $=$ East Tennessee Research and Education Center-Plant Sciences Unit; NCSU = North Carolina State University Turf Field Laboratory; UGA = Pine Hills Golf Club; LSD = least significant difference; NS = nonsignificant; red. = reduction. 


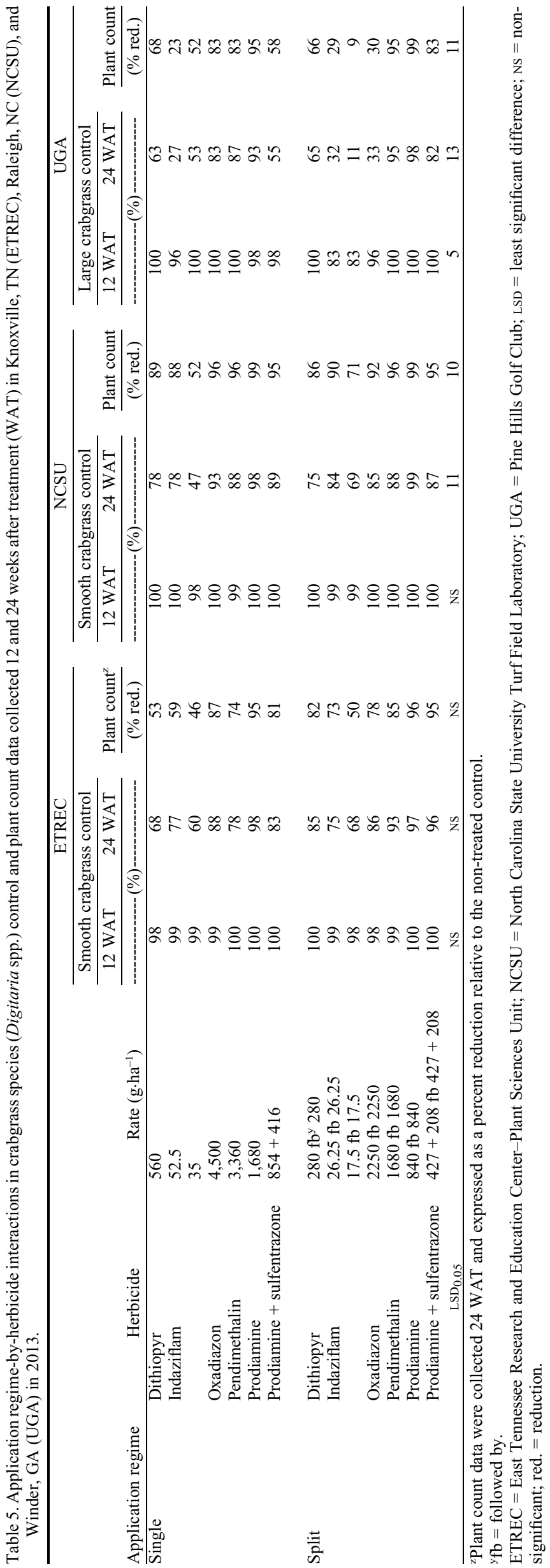

2013 at NCSU. By 24 WAIT, split applications at $17.5 \mathrm{~g} \cdot \mathrm{ha}^{-1}$ controlled crabgrass greater than a single application at $35 \mathrm{~g} \cdot \mathrm{ha}^{-1}$. Previous research indicates sequential applications of mitotis-inhibiting PRE herbicides consistently provided season-long crabgrass control (Johnson, 1977; Proctor et al., 2012). The opposite relationship was observed between single and split application regimes of indaziflam at 52.5 and $35 \mathrm{~g} \cdot \mathrm{ha}^{-1}$ at 12 WAIT and $35 \mathrm{~g} \cdot \mathrm{ha}^{-1}$ by 24 WAIT at UGA. These responses suggest that $35 \mathrm{~g} \cdot \mathrm{ha}^{-1}$ of indaziflam may not be a sufficient rate for crabgrass control in bermudagrass turf in the southeastern United States for season-long control. Overall crabgrass control with single and split applications of indaziflam at $35 \mathrm{~g} \cdot \mathrm{ha}^{-1}$ in this 2 -year study only ranged from $21 \%$ to $77 \%$, regardless of mowing height (Tables 3 and 4). With the exception of oxadiazon at UGA, significant differences were not detected between other PRE herbicides applied as a single or as split applications. Relationships among treatments using plant count data were similar to those detected by visual assessments of crabgrass control at each location. Plant count data were significantly correlated $(r=0.89, P<0.0001)$ to visual assessments of crabgrass control 24 WAIT.

Although mowing height had a pronounced effect on crabgrass control with several PRE herbicides in 2012, responses observed in 2013 were indistinct in comparison. This could be the result of variable environmental conditions over years (Table 2). During the data collection period in 2012 at ETREC, daily maximum air temperatures were $3{ }^{\circ} \mathrm{C}$ higher $\left(29^{\circ} \mathrm{C}\right)$ and rainfall accumulation $(48.5 \mathrm{~cm})$ was considerably lower than 30-year averages for this location (National Climatic Data Center, 2013). The opposite was observed in 2013 because rainfall accumulation during the data collection period $(86.5 \mathrm{~cm})$ exceeded the 30 -year average by $28 \%$ (National Climatic Data Center, 2013). At the UGA site, rainfall accumulation during the data collection period $(94.2 \mathrm{~cm})$ in 2013 exceeded the 30-year average by $54 \%$ as well (National Climatic Data Center, 2013). Increased rainfall in 2013 may have facilitated greater crabgrass germination compared with 2012, therefore making reductions as a result of increased mowing height less apparent. Several researchers have found crabgrass germination to be maximal when water potential of soil is low (i.e., conditions of ample moisture) in the top $5 \mathrm{~cm}$ (King and Oliver, 1994; Masin et al., 2005). Increased germination may in part be related to the fact that crabgrass seed moisture content must increase to $38 \%$ to $50 \%$ before germination (King and Oliver, 1994).

Residue analysis. Prodiamine residues in soil 24 WAIT varied as a result of mowing height (Table 6). At NCSU, prodiamine soil residues at the $1.5-\mathrm{cm}$ mowing height were greater than those detected at $3.8 \mathrm{~cm}$. A similar response was observed at ETREC; however, it was not statistically significant $(P=0.07)$. We surmise that increasing the 
Table 6. Mowing height-by-herbicide interactions prodiamine and pendimethalin soil residue data collected 24 weeks after treatment in Knoxville, TN (ETREC) and Raleigh, NC (NCSU) in 2013.

\begin{tabular}{|c|c|c|c|c|}
\hline \multirow[b]{3}{*}{ Mowing ht $(\mathrm{cm})$} & \multirow[b]{3}{*}{ Herbicide $^{\mathrm{y}}$} & \multirow[b]{3}{*}{$\operatorname{Rate}^{\mathrm{x}}\left(\mathrm{g} \cdot \mathrm{ha}^{-1}\right)$} & \multicolumn{2}{|c|}{ Herbicide residue in soil } \\
\hline & & & ETREC & NCSU \\
\hline & & & \multicolumn{2}{|c|}{-------- $\left(\%\right.$ of applied $\left.{ }^{w}\right)$-------- } \\
\hline \multirow[t]{2}{*}{3.8} & Pendimethalin & 3,360 & 1.0 & $<$ LOD \\
\hline & Prodiamine & 1,680 & 3.3 & 2.8 \\
\hline \multirow[t]{3}{*}{1.5} & Pendimethalin & 3,360 & 1.1 & $<\mathrm{LOD}$ \\
\hline & Prodiamine & 1,680 & 8.8 & 9.1 \\
\hline & $\operatorname{LSD}_{0.05}$ & & NS & 3.3 \\
\hline
\end{tabular}

${ }^{\mathrm{z}}$ Soil cores $(2.5 \times 2.5 \times 2.0 \mathrm{~cm})$ were collected from the center of treated plots at each location. ${ }^{\mathrm{y}}$ Herbicides were applied on 14 and 15 Mar. 2013 at Tennessee and NSCU, respectively. Prodiamine and pendimethalin residues in soil (0- to 2-cm depth) after application in Tennessee were 0.83 and $1.20 \mathrm{mg} \cdot \mathrm{kg}^{-1}$, respectively. At NCSU, prodiamine and pendimethalin residues in soil (0- to 2-cm depth) measured 3.00 and $6.60 \mathrm{mg} \cdot \mathrm{kg}^{-1}$ after application, respectively.

${ }^{\mathrm{x}}$ Data are averaged over single and split applications. Split applications were applied initially and 8 weeks later.

${ }^{\mathrm{w}} \mathrm{LOD}=$ level of detection

ETREC = East Tennessee Research and Education Center-Plant Sciences Unit; NCSU = North Carolina State University Turf Field Laboratory; LSD $=$ least significant difference; NS = nonsignificant.

bermudagrass canopy by mowing at a higher height of may limit prodiamine soil exposure at application. Although herbicide treatments were irrigated after application, it is likely that some was retained on the above-ground vegetation with greater amounts retained at the higher mowing height. In the case of prodiamine, if retained on the above-ground vegetation, it would be subject to photodegradation, perhaps decreasing its persistence (Senseman, 2007; Shaner, 2014). However, additional research is needed to confirm this theory. No difference in pendimethalin soil residue (1.1\% or less of applied) was detected at NCSU or ETREC, regardless of mowing height. This may be attributable in part to pendimethalin having a shorter soil half-life than prodiamine (Senseman, 2007).

For financial reasons, the residue analysis was limited to two of the herbicides tested in field trials. However, responses indicate that differences in crabgrass control managed under different mowing heights may not be related to degradation of evaluated herbicides in soil. Rather, a higher bermudagrass canopy may reduce the amount of light that penetrates the bermudagrass canopy, thereby reducing crabgrass germination and subsequent growth. Reduced smooth crabgrass incidence in turf mowed at higher heights of cut has been reported previously in cool-season turfgrass (Debels et al., 2012; Dernoeden et al., 1998, 1993; Dunn et al., 1981; Hoyle et al., 2014; Jagschitz and Ebdon, 1985; Voigt et al., 2001). Debels et al. (2012) noted that although both mowing height and $\mathrm{N}$ application rate affect weed incidence in cool-season turfgrasses, increasing mowing height has a more dramatic effect on reducing weed abundance than augmenting fertilizer rates when clippings are returned after mowing.

Overall, we observed that increasing bermudagrass mowing height from 1.5 to $3.8 \mathrm{~cm}$ increased the efficacy of several PRE herbicides for crabgrass control during a single year of a 2-year study. During the second year of the study, abnormally high rainfall at two locations may have diminished this response. Improved crabgrass control efficacy was likely the result of reduced $P A R$ at the soil surface and not differential breakdown of applied herbicides at the 1.5- and 3.8-cm mowing heights based on our findings. Future research should explore effects of increasing bermudagrass mowing height on $P A R$ required for crabgrass germination and growth.

\section{Literature Cited}

Anonymous, 2007. Ronstar Flo herbicide label. Bayer Environmental Sciences, Research Triangle Park, NC. p. 1-12.

Anonymous, 2009. Pendulum AquaCap herbicide label. BASF Corporation, Research Triangle Park, NC. p. 1-19.

Anonymous, 2012a. Dimension 2EW herbicide label. Dow AgroSciences, Indianapolis, IN. p. 1-17.

Anonymous, 2012b. Specticle Flo herbicide label. Bayer Environmental Sciences, Research Triangle Park, NC. p. 1-15.

Anonymous, 2012c. Barricade 4 FL herbicide label. Syngenta Professional Products, Greensboro, NC. p. $1-32$.

Busey, P. 2003. Cultural management of weeds in turfgrass: A review. Crop Sci. 43:1899-1911.

Callahan, L.M. 1978. Effects of lawn management practices on a bermudagrass turf. Tennessee Farm and Home Science Progress Report 108:37-40.

Debels, B.T., S.E. Griffith, W.C. Kreuser, E.S. Melby, and D.J. Soldat. 2012. Evaluation of mowing height and fertilizer application rate on quality and weed abundance of five home lawn grasses. Weed Technol. 26:826-831.

Dernoeden, P.H., M.J. Carroll, and J.M. Krouse. 1993. Weed management and tall fescue quality as influenced by mowing, nitrogen, and herbicides. Crop Sci. 33:1055-1061.

Dernoeden, P.H., M.A. Fidanza, and J.M. Krouse. 1998. Low maintenance performance of five
Festuca species in monostands and mixtures. Crop Sci. 38:1645-1649.

Dunn, J.H., C.J. Nelson, and R.D. Winfrey. 1981. Effects of mowing and fertilization on quality of ten Kentucky bluegrass cultivars, p. 293301. In: Sheard, R.W. (ed.). Proc. 4th Intl. Turfgrass Res. Conf., Guelph, Ontario, Canada, 19-23 July 1981. Ontario Agric. College, Univ. of Guelph, and Int. Turfgrass Soc., Guelph, Ontario, Canada.

Hall, D.W., L.B. McCarty, and T.R. Murphy. 1994. Weed taxonomy, p. 1-8. In: Turgeon, A.J. (ed.). Turf weeds and their control. Amer. Soc. of Agron., Madison, WI.

Hoyle, J.A., T.W. Gannon, and F.H. Yelverton. 2014. Effect of common bermudagrass mowing height on large crabgrass incidence. Applied Turf Sci. 11:1-2.

Jagschitz, J.A. and J.S. Ebdon. 1985. Influence of mowing, fertilizer, and herbicide on crabgrass infestation in tall fescue turf, p. 699-704. In: Lemaire, F. (ed.). Proc. 5th Intl. Turfgrass Res. Conf., Avignon, France, 1-5 July 1985. Institute National de la Recherche Agronomique, Paris, France.

Johnson, B.J. 1977. Sequential herbicide treatments for large crabgrass and goosegrass control in bermudagrass. Agron. J. 69:1012-1014.

Johnson, B.J. 1981. Effect of herbicide and fertilizer treatments on weeds and quality of Kentucky bluegrass turf, p. 19-23. In: Sheard, R.W. (ed.). Proc. 4th Intl. Turfgrass Res. Conf., Guelph, Ontario, Canada, 19-23 July 1981. Ontario Agric. College, Univ. Guelph and Intl. Turfgrass Soc., Guelph, Ontario, Canada.

King, C.A. and L.R. Oliver. 1994. A model for predicting large crabgrass (Digitaria sanguinalis) emergence as influenced by temperature and water potential. Weed Sci. 42:561-567.

Masin, R., M.C. Zuin, D.W. Archer, F. Forcella, and G. Zanin. 2005. WeedTurf: A predictive model to aid control of annual summer weeds of turf. Weed Sci. 53:193-201.

McIntosh, M.S. 1983. Analysis of combined experiments. Agron. J. 75:153-155.

National Climatic Data Center. 2013. 4 Dec. 2013. $<$ http://ggweather.com/normals/TN.html\#K $>$.

Proctor, C.A., M.D. Sousek, A.J. Patton, D.V. Weisenberger, and Z.J. Reicher. 2012. Combining preemergence herbicides in tank mixtures or as sequential applications provides season-long crabgrass control in the upper midwest. HortScience 47:1159-1162.

Senseman, S.A. 2007. Herbicide handbook. 9th ed. Weed Science Society of Amer., Lawrence, KS. p. 283-290.

Shaner, D.L. 2014. Herbicide handbook. 10th ed. Weed Science Society of Amer., Lawrence, KS. p. 283-290.

U.S. Environmental Protection Agency. 1996. Environmental chemistry methods: Pendimethalin. Washington, DC. 19 Dec. 2013. <http:// www.epa.gov/pesticides/methods/ecmmethods/ 445276-01-SW.pdf>

Voigt, T.B., T.W. Fermanian, and J.E. Haley. 2001. Influence of mowing and nitrogen fertility on tall fescue turf. Intl. Turfgrass Soc. Res. J. 9:953-956.

Webster, T.M. 2000. Weed survey of the southern states: Grass crops subsection. Proc. Southern Weed Sci. Soc. 53:247-282. 